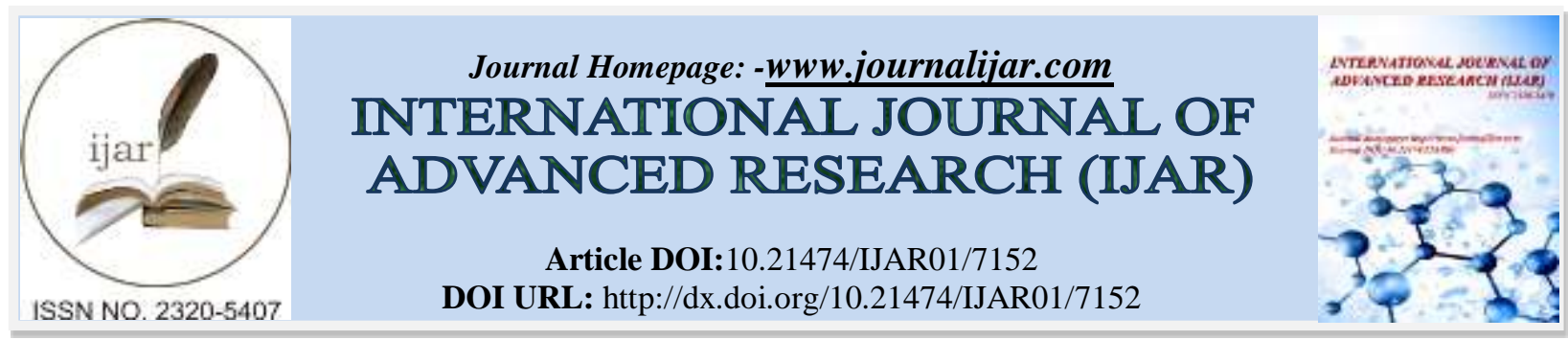

RESEARCH ARTICLE

\title{
ROLES OF OPEN AND DISTANCE EDUCATION IN THE PRODUCTION OF SCIENCE TEACHERS IN NIGERIA.
}

\author{
Dr. Yahya muhammad kamar and Dr. Suleiman sa'adu matazu. \\ Department of science and vocational education, faculty of education and extension services,usmanu danfodiyo \\ university, sokoto.
}

\section{Manuscript Info}

Manuscript History

Received: 20 March 2018

Final Accepted: 22 April 2018

Published: May 2018

Keywords:-

Science teachers, Open and distance education, scientific advancement.

\begin{abstract}
The world still needs more and better qualified science teachers despite progress made since the 2000 Dakar conference on Education for All by 2020. UNESCO (2010) indicated that some 57 million children may still be out of school in 2015, while those in school may not have the taste of basic scientific literacy due to lack of adequate number of trained science teachers. It is against this background that this paper reviewed the current status of science teachers in Nigeria, and explored the role of Open and Distance Learning (ODL) system in producing effective and dynamic science teachers to fill the existing gaps in teacher supply. Nigeria has an urgent need of providing quality science teachers to train her teaming youth who are the driving force in the development of the country. Government has responded to this need by adopting a variety of strategies of which open and distance education is one. While the paper observed poor funding as the major pitfall in the production of science teachers, it advocated functional and effective open and distance education as a catalyst for the production of qualified science teachers; who would help to eradicate illiteracy and poverty among Nigerian youth and promote scientific advancement of the country.
\end{abstract}

Copy Right, IJAR, 2018,. All rights reserved.

\section{Introduction:-}

Production of science teachers is indispensable to achieving scientific and overall development of any nation. No doubt that industrialized countries have, through their control of science education, developed the potential to increase production, and improve the standard of living of their people. Countries of the world are classified into developed, developing and underdeveloped on the account of their scientific breakthrough (Busari, 2006). Science education therefore aims at producing scientifically literate citizens as well as producing high level scientific and technological manpower (Oguniyi, 1995).

Awareness has been created about an ever increasing gap between the scientific elite and the scientific illiterate (Dushi, 1999). Scientific literacy centers on a functional understanding of the nature of science. In modern life, a scientifically illiterate person is considerably hindered in playing his/her full potential in the overall development of the society (Orukotan, 2009). This therefore implies that science education will continue to introduce positive changes which will go a long way in reducing illiteracy, poverty and so on which are impediments to national 
development. Science education also increases the chances of Nigeria achieving her desire of being transformed in every aspects of life in line with vision 20:2020

Beautiful as the above idea could be, its realization will remain a mirage if the production of qualified science teachers which are fundamental in the provision of scientific literacy and transformation of this country is not properly handled. The National Policy on Education is very explicit in referring to Open Distance Learning (ODL) as a means of salvaging the situation. ODL is refers to as open learning and distance education system that focuses on open access to education and training to make the learners free from the constraints of time and place, and offering flexible learning opportunities to individuals and groups of learners (Ghosh et al., 2012). Open and distance learning (ODL)is one of the most rapidly growing fields of education now a days and it has substantial impact on all education delivery systems. The system is not only for science teachers, but it encompasses education for all, education for life, adult and mass education, media education, personalized learning, part time studies and much more. ODL is also a major delivery mechanism of programmes run by National Teachers Institute (NTI) and National Open University of Nigeria (NOUN, 2005).

\section{The Demand For And Supply Of Science Teachers In Nigeria:-}

UNESCO (2010) reported that over 57 million children world over are out of school. About 10 million Nigerian children are out of school and even those in school may not have the taste of scientific knowledge. Reasons for this problem may not be unconnected with lack of adequately trained science teachers. In a related development, visitations to schools have shown that, there is grossly inadequate number of trained science teachers in Nigerian schools hence a mathematics teacher is made to teach physics, while biology teacher teaches chemistry and agric science (Ayogu, 2007), (Kamar \& Lawal, 2014).

Ayogu (2007) still maintained that the science teacher if available is overloaded with science subjects other than his specialization to teach, which will not augur well for effective and efficient science instruction. At primary school level, a social studies teacher may have to teach all the science and science related subjects. Jagaba, (2004) faulted the recruitment of unprofessional and unqualified teachers to teach science in Nigerian schools. This is a dilemma that needs to be urgently resolved if meaningful science education capable of transforming this country is to be achieved. Thus Open and Distance Learning (ODL) can serve as a strong vehicle that could be used to curtail this menace.

The meaningful implementation and success of any science curriculum for national development rests heavily on the availability of sufficient number and right caliber of teachers (Wasagu, 2009). Nigeria has great human resource for all sectors, and many of them could be encouraged to embrace science education, trained and equipped with practical skills and resource materials that would facilitate youth development and training in various communities. Such are positive ways to begin imparting scientific thinking and nationalism among the citizens (Wasagu, 2009). Science teacher is a central figure in the meaningful translation, interpretation and execution of the science curriculum in the classroom. The actualization of the goals and benefits of science education for the transformation of a nation is a heavy task, highly demanding on the teachers and the school system. This is because, the teacher as the implementer of the curriculum, mediates between the curriculum aims and objectives, contents and materials and the learner (Nwachukwu, 2009). The teacher is responsible for selecting the contents, materials, strategies and pedagogies, preparation and presentation of the content to learner, as well as evaluation and feedback. In addition, the teacher is faced with the task of constantly motivating and reinforcing the learners as well as provision of suitable socio-emotional atmosphere that is conducive for learning in order to achieve the desired objectives (Matazu, 2010).

For effective and efficient execution of these laudable tasks by the science teacher, Morrison (2006) advised that science teachers be properly trained, and must acquire a mastery of vast array of skills and competence, pedagogical techniques etc. Furthermore, science teachers should view learners as beginners, and adopt practical approaches, such as use of concrete materials and improvisations. Since no educational system or curriculum could rise above the quality of its teachers, and that the present status of science teachers in Nigeria might not give us the needed scientific transformation, it is pertinent that Open and Distance Learning (ODL) should come in and bridge this unimaginable gap so that the development of our teaming youth can be assured. This will translate into having scientifically literate society and the desire of Nigeria to become scientifically and technologically relevant worldwide can be achieved. 
Science education plays a vital role in the development of any nation that is why most nations of the world strive to devote sizeable proportion of their annual budgets to the development of science education. Nigerian government is not left out in the race to develop her science education sector. The National Policy on Education (2013) outlined the goals of science education as follows:

1. Producing scientists for national development

2. Cultivating inquiry, knowing and rational mind

3. Servicing studies in technology and the cause of technological development; and

4. Providing knowledge and understanding of the complexity of the physical world, the forms and the conduct of life.

Wasagu, (2009) opined that the goal of science education is having scientifically literate society could only be achieved if the country has adequate number of trained science teachers with appropriate skills and ingenuity to handle the large teaming Nigerian youth that desire to have this scientific knowledge.

The National Policy of Education (2013) set a student/ratio of 35:1 and 40:1 for basic and post-basic education level in Nigerian schools for efficiency. Contrast to this standard, statistics from three states in northern Nigeria (Kebbi, Sokoto and Zamfara) revealed a sharp difference

Table 1:-Showing Number of teachers and Students of Secondary Schools in Kebbi, Sokoto and Zamfara States as at 2005.

\begin{tabular}{|l|l|l|l|l|}
\hline State & No of Teachers & No of Students & Student-Teacher Ratio & Remarks \\
\hline Kebbi & 1,872 & 113,946 & $61: 1$ & Below standard \\
\hline Sokoto & 1,833 & 81,380 & $44: 1$ & Below standard \\
\hline Zamfara & 1,164 & 80,995 & $70: 1$ & Below standard \\
\hline
\end{tabular}

Source: Statistics of Education in Nigeria 1999-2005.

Table 2:-Showing Number of Teachers and Pupils of Primary Schools in Kebbi, Sokoto and Zamfara States as at 2005.

\begin{tabular}{|l|l|l|l|l|}
\hline State & No of Teachers & No of Pupils & Pupils-Teacher Ratio & Remarks \\
\hline Kebbi & 8,460 & 324,469 & $38: 1$ & Within standard \\
\hline Sokoto & 6,939 & 630,426 & $91: 1$ & Below standard \\
\hline Zamfara & 4,736 & 350,627 & $74: 1$ & Below standard \\
\hline
\end{tabular}

Source: Statistics of Education in Nigeria 1999-2005.

With this unimaginable ratio, particularly in Kebbi and Zamfara states at secondary school level and in Sokoto and Zamfara states at primary school level, one cannot expect efficiency let alone transfer of scientific knowledge or literacy. No wonder, Akpan (2008) said in terms of access to science education, only $30 \%$ of all Nigerian secondary education students are studying science, while the science:art ratio in universities is 57:43 as against the policy prescription of 60:40; in the polytechnics, it was 46:54 as against the policy prescription of 70:30. It is therefore clear that there is a gap between unsatisfied demand for education and the actual supply of educational services. Calvet, (1999) opined that this gap is what Open and Distance Learning (ODL) set to bridge as it helps to extend the market for education to clientele who have not been previously served. The problem of unsatisfied demand for education and actual supply of educational services contributed greatly to the acceptance, growth and implementation of Open and Distance Learning (ODL) in Nigeria as a means to bridge the gap between demand and supply of educational services in general and science education in particular. This is the ugly scenario that open and distance education in Nigeria could certainly salvage.

\section{Access To Science Education At Universities: The Need For Odl To Bridge The Gap:-}

In an effort to encourage the study of sciences in the Nigerian universities and by extension to have a sufficient number of adequate trained science teachers for the nation's primary and secondary schools, the Federal Government guidelines on admissions stipulate intake of $40 \%$ for Art courses and $60 \%$ for science courses in conventional universities. This implies that, admissions into universities should reflect a trend where more candidates are admitted into sciences than art courses. Findings from the Research Monitoring and Evaluation Department, JAMB (2006) revealed that only Benson Idahosa University, Benin a private conventional university 
that strictly complied with this national standard. However, statistics revealed that seven universities complied to a high degree.

Table 3:-Universities that complied to high degree

\begin{tabular}{lc}
\hline Universities & Art:Science \\
\hline Madonna University, Okija & $46: 54$ \\
University of Uyo, Uyo & $46: 54$ \\
Abia State University, Uturu & $45: 55$ \\
University of Ibadan, Ibadan & $44: 56$ \\
University of Lagos, Lagos & $42: 58$ \\
University of Maiduguri, Maiduguri & $37: 63$ \\
University of Jos, Jos & $37: 63$ \\
\hline
\end{tabular}

Source: JAMB Research Monitoring and Evaluation Department (2006)

Nineteen universities however admitted more candidates into the arts/ arts related courses than into sciences/ science related courses. These universities admitted between 11 and $22 \%$ in excess for art courses depriving the science in the same ratio. This is clearly against the stipulation of the guidelines which encourages more enrolment into the sciences than arts.

Table 4:-Universities that admitted excess arts students

\begin{tabular}{ll}
\hline Universities & Art:Science \\
\hline Kogi State University, Anyigba & $82: 18$ \\
Nassarawa State University, Keffi & $80: 20$ \\
Benue State University, Makurdi & $76: 24$ \\
Adekunle Ajasin University, Akungba-Akoko & $74: 26$ \\
Bowen University, Iwo & $71: 29$ \\
Obafemi Awolowo University, Ile-Ife & $71: 29$ \\
Imo State University, Owerri & $69: 31$ \\
Babcock University, Ilishan Remo & $69: 31$ \\
Ebonyi State University, Abakalike & $67: 33$ \\
Delta State University, Abraka & $67: 33$ \\
Adamawa State University, Mubi & $67: 33$ \\
Covenant University, Ota & $59: 41$ \\
University of Calabar, Calabar & $59: 41$ \\
Ambrose Ali University, Ekpoma & $59: 41$ \\
Olabisi Onabanjo University, Ago-Iwoye & $58: 42$ \\
Usmanu Danfodiyo University, Sokoto & $57: 43$ \\
University of Ilorin, Ilorin & $57: 43$ \\
University of Benin, Benin & $53: 47$ \\
Igbinedion University, Okada & $51: 49$
\end{tabular}

Source: JAMB Research Monitoring and Evaluation Department (2006)

This situation showed with greater emphasis that Nigerian universities could not provide adequate manpower in science and science related courses thus the need for Open and Distant Learning as a viable means of producing science teachers capable of transforming the country into scientifically literate society.

In a related development, Research Monitoring and Evaluation Department, JAMB (2006) revealed that while nine universities admitted students below their carrying capacity, thirteen universities admitted in excess of their carrying capacity. The universities that admitted with a shortfall of their carrying capacity and the percentage deviation as at 2003/2004 session are as follows:

Table 4:-Universities that admitted below their carrying capacity

$\begin{array}{ll}\text { Ebonyi State University, Abakalike } & 59 \% \\ \text { University of Agriculture, Abeokuta } & 37 \% \\ \text { University of Ibadan, Ibadan } & 32 \%\end{array}$




$\begin{array}{ll}\text { University of Uyo, Uyo } & 24 \% \\ \text { University of Calabar, Calabar } & 24 \% \\ \text { Abubakar Tafawa Balewa University, Bauchi } & 12 \% \\ \text { Abia State University, Uturu } & 6 \% \\ \text { Michael Okpara University of Agriculture, Umudike } & 4 \% \\ \text { Obafemi Awolowo University, Ile-Ife } & 1 \%\end{array}$

Source: JAMB Research Monitoring and Evaluation Department (2006)

The universities that admitted in excess of their carrying capacity and the percentage deviation as at 2003/2004 session are as follows:

Table 4:-Universities that admitted above their carrying capacity

$\begin{array}{lc}\text { Kogi State University, Anyigba } & 62 \% \\ \text { Nnamdi Azikiwe University, Awka } & 55 \% \\ \text { Federal University of Technology, Owerri } & 49 \% \\ \text { Ambrose Ali University, Ekpoma } & 37 \% \\ \text { University of Benin, Benin City } & 36 \% \\ \text { University of Agriculture, Makurdi } & 28 \% \\ \text { Usmanu Danfodiyo University, Sokoto } & 17 \% \\ \text { University of Jos, Jos } & 12 \% \\ \text { Adamawa State University, Mubi } & 10 \% \\ \text { University of Ilorin, Ilorin } & 6 \% \\ \text { University of Lagos } & 4 \% \\ \text { Federal University of Technology, Akure } & 4 \% \\ \text { University of Maiduguri, Maiduguri } & 3 \%\end{array}$

Source: JAMB Research Monitoring and Evaluation Department (2006)

This scenario indicated that quite a number of universities are admitting above their carrying capacity and even with that, they cannot cater for all those who desire to have higher education, most especially, science education. This also justified the need for ODL to curtail that excesses. It is on this note that ODL through its institutions such as NTI, NOUN offer variety of programmes in science and science related areas in addition to other programmes which help to prepare and produce science teachers for the society. These science teachers when produced will compliment the ones produced by conventional institutions and will help our teaming youth with basic scientific literacy and facilitate the transformation of the country into a technologically developed nation by 2020 .

In conjunction with cooperating universities, NTI runs programme of ODL which offer Integrated Science and Primary Education Studies thereby providing access to science education for more candidates. The NTI ODL programmes are run on Course Modular Systems of 120 modules for the NCE spread across five years during school vacation periods. This is a golden opportunity for candidates who are unable, for one reason or the other to enroll into the regular 3 year NCE programme in colleges of education.

\section{Open And Distance Learning (Odl) In Nigeria:-}

Open and Distance Learning as the name states is that education provided to those people who found it difficult to access education at and in their own peculiarities. It is a "new way of learning, providing access to qualitative education for those whose aspirations for higher education is hindered for reasons such as academic deficiencies at the O/level or not being able to quit their job or business to study" (NOUN 2010). Several Open and distance learning bodies exist in the world over, some of these are:

1. International Council for Distance Education (ICDE),

2. Open University of United Kingdom (OUUK)

3. Indira Ghandi National Open University (IGNOU) India.

4. Open University of Hong kong (OUHK)

5. Athabaska University, Canada

6. University of South Africa (UNISA)

7. Open University of Tanzania (OUT)

8. University of the Philipines-Open University (UPOU) 
9. National Open University of Nigeria (NOUN) and,

10. The National Teacher's Institute (NTI).

All the above mentioned countries and other countries that are not mentioned as well have one objective of ODL, which is the provision of access to education to individuals that for one reason or the other cannot go to the class to learn. However, the essence is to expand educational opportunities to the semi-adult and adult population (Ghosh, et al, 2012). Just like Nigeria other countries are not without challenges of achieving the goal of the ODL (Arinto, 2016)

Since independence, Nigeria has continued to demonstrate an irrevocable and unwavering commitment to education as a tool for national development, and as an inalienable right of her citizens. The socio-economic dimensions of providing education for all are huge, bearing in mind the population of the country and the competing demands for resources amongst the compelling needs of the society (Adisa \& Lawal 2009). It must have occurred to the Federal Government that the ever growing demand for education by her people cannot be met by the traditional means of face to face classroom instructional delivery. It is on that note that National Teachers' Institute (NTI), and National Open University of Nigeria (NOUN) were established in order to produce better and up to date science teachers to meet up with the challenges of teacher production.

The National Policy on Education (2013) stated that Open and Distance Learning (ODL) is the mode of teaching in which learners are removed in time and space from the teacher. It uses a variety of media and technologies to provide and/or improve access to good quality education for large number of learners wherever they may be. This is a right step in the right direction for a country like Nigeria with large number of youth seeking for scientific literacy that will enable them to contribute their quota to national development.

For government to meet its educational obligations of providing access to quality education in general and science education in particular, to all level by all who desire it, qualified teachers must be produced. Thus the place of Open and Distance Learning (ODL) in Nigeria cannot be overemphasized if this goal must be achieved.

It is on that note, the National Open University of Nigeria (NOUN 2010) outlines some of the roles of Open and Distance Learning (ODL) as follows:

1. Ensure equity and equality of opportunities in education

2. Provide a wider access to education

3. Enhance Education for All (EFA)

4. Provide the entrenchment of global learning culture

5. Provide instructional resources via an intensive use of information and communication technology

6. Provide flexible, but qualitative education; and

7. Reduce the cost, inconveniencies and increase access to education and its delivery

It is pertinent to focus on the philosophy of education in Nigeria which states that education is compulsory and a right of every Nigerian irrespective of gender, social status, religion, ethnic background and any peculiar individual challenges; functional and relevant to the needs of the society. It is also the philosophy of education in Nigeria to develop individual into a sound and effective citizen and provide 'equal opportunities for all citizens of the nation at the basic, secondary and tertiary levels both inside and outside the formal school system"' (FRN, 2013).

A fundamental characteristic of open and distance learning is that it is learner-centered. A learner-centered educational process means departing from the conventional teaching and learning culture to one which employs a wide range of tools to effect learning outcomes. These include printed course units and readers, tutor-and-computer marked assignment and feedback systems, radio and television broadcasts, audio and video tapes etc.

\section{Open And Distance Learning And National Development:-}

Education is inherently a developmental process. Indeed, it can be said that if the expertise necessary for expansion of distance education programmes had not been available, the education policies and developmental issues in place today would have excluded many Nigerians and Africans. Most pioneers of education in Nigeria were products of the British correspondence system and the London matriculation exam. In the absence of domestic higher institutions in Nigeria prior to 1948, the nation's first students learned through the distance education modality and eventually graduated to become valuable resource persons whose ground breaking work 
kick-started the establishment of Nigeria's first schools and institutions of higher education which, in turn, served as springboards for national development. These "pioneering experts" constituted the initial core of administrators and educators that supported educational planning, teacher education, policy formulation, and developmental initiatives in Nigeria.

Records from these distance institutions reveal that Nigeria's teaching and educational system, which clearly faced an acute shortage of teachers during the introduction of the Universal Primary Education programme in 1976, and later the Universal Basic Education in 1999, were unquestionably strengthened through the introduction of new teachers produced via ODL modalities. The NTI's Pivotal Teacher Training Programme, designed to support the introduction of the Universal Basic Education scheme introduced in 1999, produced 19,025, and 20,800 qualified teachers for years 2000, and 2001 respectively (Aderinoye, 2001). These activities of NTI have helped to maintain stability, quality, high rates of retention, and have reduced the dropout rates at the basic level of education across the country.

\section{Challenges Of Open And Distance Learning (Odl) Programme In The Production Of Science Teachers In Nigeria:-}

Beautiful as the ODL programme may be, the following challenges need to be properly handled to enhance its role in the production of science teachers in Nigeria:

1. Funding of the programme: Open and Distance Learning is capital intensive and therefore proper and sufficient funding need to be accorded to it for proper actualization of its goals. Funding which is pivotal, but grossly lacking not only to ODL program, but the general education sector needs to be properly looked into by government. There is need for Nigeria to increase its budgetary allocation to education from $0.9 \%$ of its GDP upwards. Other sub-saharan countries in Africa allocate up to $4 \%$ of their GDP.

2. Access to technology: The cost of personal computer (PC) and laptops is still very high in Nigeria and this made it impossible for an average Nigerian to have one. Those who are privileged to have PC are not connected to the internet due to extra cost which they cannot afford. In addition to that, other telecommunication facilities are not effective in terms of service provided and are equally expensive. Even with the introduction of cell phones in August 2001, access is still limited because most rural areas are not connected.

3. Problem of electricity: Since successful ODL cannot be assured without the use of communication and technological tools (e-mail, fax, internet, television, radio, etc), then the problem of electricity comes into focus. Several rural areas in Nigeria are yet to have electricity, while the urban areas experience epileptic power supply. This has create problem of effective integration of most technological media in the delivery of ODL programmes.

4. Laboratory practical experience: Since distance and contact are not a barrier in ODL programmes, and that for a trained science teacher to be effective, he/she must have a practical aspect of science, then inadequate access to laboratory practical experience is a problem. This implies that most of the science teachers produced by ODL will have a technical problem when it comes to practical/laboratory work. This is a dilemma that needs to be overcome if quality and efficient science teachers must be produced by ODL programme.

5. Monitoring: As ODL has the potential for unlimited number of students, there is the need for proper and effective monitoring of designated study centres to ensure genuineness of students enrolled for various courses. Such monitoring is equally important during examination to ensure that it is the right candidates that are writing the right examination at all centres and all online examinations.

The implication of these challenges is that the internal efficiency of ODL programmes is lowered. This gives rise to public outcry on the quality of ODL programmes and their products.

\section{Recommendations:-}

The following are recommended as a way forward for ODL in order to produce quality science teachers in Nigeria.

1. Proper funding of ODL for efficiency: Government and other stakeholders should as a matter of urgency release sufficient fund to the program to enable it produce quality science teachers. Equally important, serving science teachers should be allowed to go for retraining at ODL centres.

2. Government and other stakeholders should be involve in the supply and importation of PCs, laptops, radios, DVDs and other ICT facilities in order to make them affordable to all students in ODL programmes 
3. Since availability of electricity is cardinal to the success of ODL programmes, then Non-Governmental Organizations (NGOs) should assist government in the provision of electricity to rural and urban areas where it is not readily available.

4. NTI, NOUN and other ODL agencies should collaborate with public and private institutions to improve and use their laboratory facilities for hands-on training of students under the ODL programmes. This will go a long way in reducing the gap and enhancing practical science teaching and learning.

5. NTI, NOUN and other ODL agencies should adopt and ensure more proactive monitoring mechanisms. This will knock out doubt and enhance acceptability of their products.

\section{Conclusion:-}

The paper looked at the status and tasks of science teachers in Nigeria, ways by which Open and Distance Learning (ODL) can serve as a catalyst for the production of quality science teachers in Nigeria. Challenges that could affect this desire were highlighted and possible solutions were offered. If properly employed, the ODL programme will remain a vehicle that will take Nigeria to the desired level in terms of production of qualified science teachers for the nation's post basic institutions.

\section{References:-}

1. Arinto, P. (2016). Issues and Challenges in Open and Distance E-Learning: Perspective from the Philippines. International Journal of Review in Research in Open and Distance Learning, Vol 17 (2), 162-180

2. Abdullahi, A. (1982). An investigation into the status of Primary Science in Nigeria. Journal of Science Teachers Association of Nigeria. 20 (2): 193-199

3. Aderinoye, R. A. (2001). Teacher Training by Distance: The Nigerian Experience. In John Daniels (Ed.) Proceeding of the 1995 ICDE Conference. Birmingham, UK.

4. Adisa, J. and Lawal A. (2009). Analyzing the Challenges of Open and Distance Education as a Means of Achieving Sustainable Development in Nigeria. Farfaru Journal of Multi-Disciplinary Studies, 4, 513.

5. Akpan, B. B (2008). Nigera and the Future of Science Education. Science Teachers Association of Nigeria. Ibadan.

6. Ayogu, Z.U. (2007). Challenges of Science Technology and Mathematics (STM) education policy implementation in Nigerian schools. Science Teacher Today. Journal of School of Sciences, FCET, Eha-Amufu. 4 (1): 13.

7. Calvert, B. (1999). Facilitating Transfer of Distance Courses. Paper presented at the 8th World Conference on Development and Social Opportunity, Delhi, India: Open University Press.

8. Dushi, R.A. (1999). Restructuring Science Education: The Importance of Theories and their Development. Colonial Teachers College Press. Ibadan

9. Federal Ministry of Education (2007). Statistics of Education in Nigeria: 1999-2005. Statistics and NEMIS Branch. Abuja.

10. Federal Republic of Nigeria (2009). National Policy on Education Roadmap for Nigerian Education Sector.

11. Federal Republic of Nigeria (2013). National Policy on Education ( $6^{\text {th }}$ Edition): Lagos. NERDC press.

12. Ghosh, S., Nath, J., Agarwal, S. \& Nath, A. (2012). Open and Distance Learning (Odl) Education System: Past, Present and Future - A Systematic Study of an Alternative Education System. Journal of Global Research in Computer Science, vol 3, (4) Pp 53-57.

13. Jagaba, M.M. (2004). Strategies for Improving the Quality of Primary Education under U.B.E. program, Sokoto Educational Review, 6 (2): 13-25.

14. Kamar, Y.M. \& Lawal, N.I. (2014). Agricultural Science Curriculum: Problem and Prospect for Effective Implementation in Nigerian Institutions of Learning. Journal of Vocational and Technical Education JOVTED 9(1)

15. Matazu, S.S. (2010). The Relevance of Science, Technology and Mathematics Education in Developing Skills for Self Reliance: The Nigerian Experience. African Journal of Teacher education (AJOTE). 1. (I), 222-229.

16. Morrison, J. (2006). Ties STM Education Monograph Series: Attributes of Science, Technology and Mathematics Education. Wadswoth Publishing Company Belmont U.K.

17. National Open University of Nigeria, (2005). A Profile of National Open University of Nigeria. Lagos

18. National Open University of Nigeria, (2010). Getting to Know Your University, an Orientation and Information Guide for Students of NOUN. Lagos

19. Nwachukwu, C. (2009). The Relevance of Science, Technology and Mathematics Education to Development of Entrepreneurial Skills. STAN Proceedings. 
20. Oguniyi, M.B. (1995). The Moral Imperative, a Science Educator's View Points. STAN Proceedings.

21. Orukotan, A.F. (2009). Curriculum Enrichment of STM Education as a Basis for Sustainable Development. STAN Proceedings. $50^{\text {th }}$ Anniversary Conference.

22. UNESCO (2010). Education for National Development. Retrived on $12^{\text {th }}$ Octorber, 2011, from http://wikipediaorg/.

23. Wasagu, M.A. (2009). Rethinking Science Education for the Changing Times: The Writing on the Wall. $8^{\text {th }}$ Inaugural Lecture of the Usmanu Danfodiyo University, Sokoto.

24. Joint Admission and Matriculation Board (2006). Admission into Nigerian Universities: Monitoring Report. 